\title{
Cancer 'cure' article stirs up hot debate
}

[WASHINGTON] The presentation of a US newspaper story about innovative cancer research was last week criticized by cancer specialists, science-media watchers and biotechnology investors. They said the New York Times raised patients' hopes unrealistically and sent the stock market into a frenzy that was bad for both investors and industry.

"You have to think twice before you put a story above the fold on the front page about a drug and use the word cure when it really doesn't even exist in drug form today," says David Kessler, former commissioner of the Food and Drug Administration.

"People who should know better simply [got] involved in the hype. I would not exclude even members of the top echelons of the National Institutes of Health," says Spyros Andreaopoulos, director emeritus of the office of communications at Stanford University Medical Center in Palo Alto, California, who has written widely on the interplay of science and the media.

The article, which ran on 3 May in the widely-read Sunday edition under the headline 'A Cautious Awe Greets Drugs That
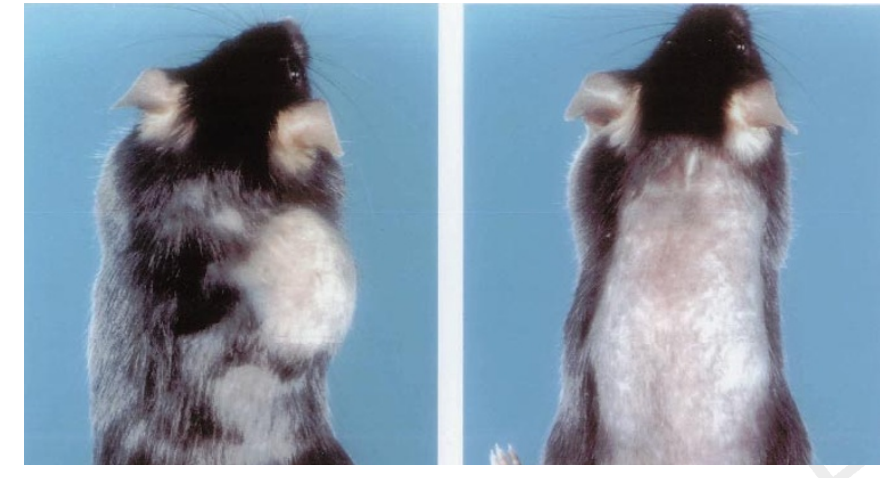

Signs of hope: in Folkman's laboratory, the lung cancer tumour visible (left) was reduced after 12 days' endostatin therapy (right)
Eradicate Tumors in Mice', featured enthusiastic quotations from Nobel prizewinner James Watson and Richard Klausner, director of the National Cancer Institute. It described the work of Judah Folkman, a cancer researcher at the Children's Hospital in Boston, in whose laboratory the substances endostatin and angiostatin were discovered.

These natural substances work by choking the blood supply of cancers, and Folkman has said that in combination they eradicate all kinds of tumours in mice without inducing resistance or obvious side-effects.

\section{Reporter backs away from lucrative book deal}

[WASHINGTON] The day after the cancer research story appeared in the New York Times, the reporter responsible for it was negotiating with publishers about a book deal that an influential agent had promised would bring her a $\$ 2$ million advance.

News of the deal, first reported in the Los Angeles Times of 6 May, fuelled suspicion that the two events may have been jointly planned, although this is vigorously denied by both the reporter, Gina Kolata, and her agent, John Brockman.

Kolata quickly withdrew from the deal once issues about a possible conflict of interest had arisen. But the episode had already made its mark. "That someone might have written a story with the idea that this could lead to an enormously lucrative book deal is very unsettling," says Allen Lichter, president-elect of the American Society of Clinical Oncology.

Brockman says the deal was his idea, and that he suggested it to Kolata the Sunday her story appeared. Kolata confirmed his account through a New York Times spokeswoman.

Brockman - who represents 175 scientists and science writers including Sir John Maddox, former editor of Nature, and Richard Dawkins - says that, on reading the story, he telephoned Kolata from his Connecticut farmhouse and told her: "I can get you two million dollars".

He says she at first resisted because of another book commitment, but by late Sunday had written the proposal and forwarded it to him by e-mail. Brockman sent the proposal to publishers at midnight, and by 9.30 on Monday morning had the first offer from a major New York publishing houses, he says.

On Tuesday, after several reporters had phoned Brockman enquiring about the book proposal, he says that he phoned Kolata, who "was very upset", and told him: "I don't like this; I can see what's coming; I just don't think I can do this." She phoned Brockman later that day and asked him to withdraw the proposal.

Kolata referred calls to New York Times spokeswoman, Nancy Nielsen, who says that "after [Kolata] had some

discussions with her editors, she decided to withdraw her book proposal", though the decision was entirely hers. The New York Times says it asks reporters not to write books on developing stories that they are still covering.

Brockman says that it would have been proper for Kolata to write a book on an issue that is newsworthy, because the "hypothetical" questions raised about conflict of interest disappear in the case of Kolata, who is "totally ethical".

Instead, he says, because of a misplaced outcry, "the ace reporter on biomedical issues is not going to write a book. Is that good?"

M.W.
Watson was quoted as saying that "Judah is going to cure cancer in two years". The article also quotes Klausner calling the drugs "the single most exciting thing on the horizon" for cancer treatment, and adding "I am putting nothing on higher priority than getting this into clinical trials".

Since the publication, both have modified their statements, or at least the story's presentation of them. The optimistic tone and prominent placement of the story - the top of the front page - sparked controversy.

Biotechnology investors pointed out that it ignored other important contexts, such as that a dozen or more laboratories are working on compounds that also seek to inhibit blood supply to tumours, and that many are further along in their research.

"There are 20 other companies with antiangiogenesis programmes. And most of them are more advanced really," says Stelios Papadopoulos, a biophysicist who is an investment banker specializing in biotechnology at PaineWebber in New York.

Cancer physicians complained they were flooded with calls from patients demanding the substances, which are not yet produced in sufficient quantities to launch human clinical trials and are thus years from availability, even if they surmount the hurdles.

Allen Lichter, a radiation oncologist at the University of Michigan who takes over as president of the American Society of Clinical Oncology at the annual meeting this coming weekend, says that the article was "cruel" in "inappropriately" raising hopes about a treatment that may never translate successfully from mice to men. "It builds cynicism that what people read about cancer research cannot be relied upon. That will accrue to our detriment over time," Lichter says.

But Nancy Nielsen, a spokeswoman for the New York Times, defends the handling of the story, arguing that the quotation from Watson made it "distinctive" and that the article described "an optimistic trend becoming apparent in scientists' thinking about a variety of recent lab developments".

At least one prominent scientist agreed. The molecular biologist and 1959 Nobel laureate Arthur Kornberg, of Stanford Universi- 
ty, says that the story deserved its front-page slot. "Something newsworthy has been found," Kornberg said, although he added he would have preferred the story to have been "a little more cautionary".

Watson and Klausner later toned down their remarks. Watson, in a letter to the newspaper published on 7 May, said "my recollection of the conversation [with the New York Times reporter] is quite different". But in the letter, he calls the work "the most exciting cancer research of my lifetime".

Wendy Goldstein, a spokeswoman for the Cold Spring Harbor Laboratory on Long Island, where Watson is president, said Watson was contesting the quotation attributed to him "because he feels a statement from him has offered what could very well prove to be false hope to a great many people".

The New York Times says it stands by the Watson quotation. But on 8 May it admitted it had imprecisely paraphrased Klausner by using the words "The National Cancer Institute has made the drugs their top priority" to describe his statement "I am putting nothing on higher priority".

In the Los Angeles Times of 6 May, Klausner - who could not be reached later last week - sounded a cautionary note, saying "We have cured mice of cancer for decades and it simply didn't work in humans."

Scientists argued last week that nothing in the New York Times story was news to those in the field. Folkman's early results with one of the substances, endostatin, in a particular mouse lung cancer were published in Nature last November (see 390, 404; 1997), and he has discussed results with both substances in scientific meetings for 18 months.

Nevertheless, the day after the news story appeared, shares in Entremed, the small company in Rockville, Maryland, founded to make the drugs, soared from $\$ 12.06$ to more than $\$ 80$ before closing at $\$ 51.81$. (They fell back to $\$ 33.25$ by the end of the week.)

Two other biotechnology companies Sugen and Magainin Pharmaceuticals also saw their share prices rise by 20 per cent and 38 per cent respectively. Both are working with similar compounds - known as angiogenesis inhibitors because they stop the growth of new blood vessels. But these compounds are already in human trials.

Biotechnology investors complain that the stock market's reaction damaged the industry. "It dilutes the impact of future more definitive work by this company or others, and results in a potential misallocation of capital away from more proven treatments," says one New York investment banker, who calls the story "a bad thing for science and for biotechnology".

Experienced investors said the market's reaction - 23.5 million shares of Entremed were traded the day after the story was published - was driven by ordinary investors who engaged in momentum buying, in which people hurriedly buy a stock thinking that it may never be as cheap again.

Entremed's experience clearly stimulated some scientists into thinking about ventures of their own. David Nance, president and chief executive officer of Introgen Therapeutics, a company in Austin, Texas, that funds biotechnology start-ups, says that in conversations last week with researchers, all wanted to know: "If we go public fast, and publish this animal data showing this, is it worth a billion dollars these days?"

He told them "don't be ridiculous". Perhaps, he says, "if they were Nobel candidates and had reputations like Dr Folkman, maybe this would happen again in history. But don't count on it."

MeredithWadman

\section{EPA laboratories are 'still struggling' with change three years on}

[WASHINGTON] Three years after the US Environmental Protection Agency (EPA) revamped its network of research laboratories, the labs are still struggling with the change, says the agency's Board of Scientific Counselors (BOSC).

Of particular concern is the scientific workforce, which it says is stretched thin and in some cases unsuited to its new tasks.

BOSC, set up in 1996 to advise EPA's Office of Research and Development (ORD) on its programmes and research agenda, relied mainly on written self-assessments by laboratory managers together with brief site visits by board members for its report.

Despite the speed with which BOSC worked - the review took only a few months - EPA science managers who have read drafts say they are impressed with its perceptive analysis. The final report goes to Congress and ORD this week.

BOSC looked at ORD's three national laboratories, each with dispersed divisions, and its two Washington-based 'national centres': the National Center for Environmental Research and Quality Assurance (NCERQA) and the National Center for Environmental Assessment. All are part of ORD, which conducts more than 80 per cent of EPA's research and has a budget of $\$ \mathbf{5 7 0}$ million this year.

Of the three main laboratories, the National Health and Environmental Effects Research Laboratory (NHEERL)has adapted best to ORD's new emphasis on risk-based research, increased extramural grants and more rigorous peer review.

But reorganization has left the National Exposure Research Laboratory (NERL) short of scientific talent. In five years, it has lost half its budget, 28 per cent of employees and 45 per cent of contract researchers.

Now, says BOSC, the laboratory is "not self-sufficient in personnel and/or funding to carry out many of the large-scale research programs that fall under its mandate". Morale at the NHEERL improved after the reorganization; at NERL it "has not created any scientific excitement" and has not changed research methods.

Also facing manpower problems is the National Risk Management Research Laboratory (NRMRL) in Cincinnati, Ohio, which focuses on environmental cleanup and pollution prevention. The laboratory has skilled environmental engineers, says BOSC, but lacks many other professionals, from economists to microbiologists to behavioural scientists, needed for a broader role in risk assessment and management.

In recent congressional testimony, BOSC's chairman, Costel Denson, the University of Delaware's vice provost for research, said EPA needs "an orderly plan and program to enhance or redirect the skills of many of the scientists in ORD".

ORD managers recognize the need for new blood. The average age of its almost 2,000 employees is 48 , and many are expected to retire in the next few years. EPA asked the White House budget office for money to hire 200 postdoctoral researchers in 1999, but was granted enough for only 50.

Many EPA researchers feel hampered in collaborating with other scientists, the BOSC report says. They lack funds to attend meetings and believe - mistakenly, say ORD managers - that conflict-of-interest rules prevent them from interacting with outside scientists supported by EPA research grants.

Most of these grants are administered by the NCERQA under its Science to Achieve Results (STAR) initiative, which has grown in a few years from $\$ 20$ million to a $\$ 100$ million-a-year programme. This rapid growth, although considered positive, has taken its toll on NCERQA staff.

Grant administrators say workloads have increased so much that "they are now unable to dedicate the desired level of attention to the technical content of the research", the BOSC report says. NCERQA plans its own review of STAR this year.

But more than reviews, ORD needs money, says the agency's Research Strategies Advisory Committee. In an April report to the EPA administrator, Carol Browner, it pointed out that ORD's 1999 budget request was the lowest of the decade when adjusted for inflation. This comes as several major research projects are starting, including studies of particulate matter, endocrine disruptors, and microbial pathogens in drinking water.

Tony Reichhardt 